\title{
Are Chileans exposed to dietary furan?
}

Mariotti, Maria S.; Toledo, Carla; Hevia, Karen; Gomez, J. Pablo; Granby, Kit; Rosowski, Jaime; Castillo, Oscar; Pedreschi, Franco

\author{
Published in: \\ Eurofoodchem XVII - Book of abstracts
}

Publication date:

2013

Link back to DTU Orbit

Citation (APA):

Mariotti, M. S., Toledo, C., Hevia, K., Gomez, J. P., Granby, K., Rosowski, J., Castillo, O., \& Pedreschi, F. (2013). Are Chileans exposed to dietary furan? In H. Köksel (Ed.), Eurofoodchem XVII - Book of abstracts (pp. 333). Hacettepe University.

http://www.arber.com.tr/eurofoodchemxvii.org/arkakapi/cache/flfilDocumentFile187.pdf

\section{General rights}

Copyright and moral rights for the publications made accessible in the public portal are retained by the authors and/or other copyright owners and it is a condition of accessing publications that users recognise and abide by the legal requirements associated with these rights.

- Users may download and print one copy of any publication from the public portal for the purpose of private study or research.

- You may not further distribute the material or use it for any profit-making activity or commercial gain

- You may freely distribute the URL identifying the publication in the public portal

If you believe that this document breaches copyright please contact us providing details, and we will remove access to the work immediately and investigate your claim. 


\title{
ARE CHILEANS EXPOSED TO DIETARY FURAN?
}

\section{María S. Mariotti ${ }^{1}$, Carla Toledo ${ }^{1}$, Karen Hevia ${ }^{1}$, J.Pablo Gomez ${ }^{1}$, Kit Granby ${ }^{2}$, Jaime} Rosowski ${ }^{3}$ Oscar Castillo ${ }^{3}$, and Franco Pedreschi ${ }^{1}$.

\author{
${ }^{1}$ Departmentof Chemical Engineering andBioprocess, Pontificia Universidad Católica de Chile, Av \\ Vicuña Mackenna 4860, Santiago, Chile. \\ ${ }^{2}$ Technical University of Denmark, National Food Institute, Mørkhøj Bygade 19, Søborg, DK-2860, \\ Copenhagen, Denmark. \\ ${ }^{3}$ Departmentof Nutrition, Diabetes and Metabolism. School of Medicine, Pontificia Universidad \\ Católica de Chile, Lira 40, Santiago, Chile \\ E-mail presenting author: msmariot@uc.cl
}

The occurrence of furan a possible carcinogen for humans (2B) in several thermally treated foods has caused concern into health world organizations, which have emphasized the need to increase the database information on the dietary human exposure to this compound.

In this sense, although Chilean consumer preferences include foods which may content considerable amounts of furan, currently there is no information regarding to dietary exposure to furan in Chile. Thus, the objective of this work was to determine the Chilean exposure to dietary furan.

For accomplishing this purpose, the furan concentration of 13 types of highly consumed commercial foods processed at high temperature (dairy products, baby foods, fruit juices, potato crisps, breakfast cereals, "marraqueta" and "hallulla" Chilean type breads, "sopaipillas" Chilean fried dough, cookies, biscuits, canned foods, fried and cooked fish, roast meat and coffee) were analyzed based on an optimized GC-MS method. In addition, risk assessment studies, mainly on the exposure estimate, were calculated based on diet data of Chilean individuals obtained from national studies.

Of the food items surveyed not only coffee $\left(530 \mathrm{ng} \mathrm{g}^{-1}\right)$ but also low moisture starchy products like potato crisps, "Soda" type biscuits and toasted bread presented the highest furan concentration (200 ng $\mathrm{g}^{-1}, 110 \mathrm{ng} \mathrm{g}^{-1}$ and $190 \mathrm{ng} \mathrm{g}^{-1}$ respectively). Furthermore, samples of breakfast cereals contained furan levels up to $30 \mathrm{ng} \mathrm{g}^{-\mathrm{t}}$. Furan was also found in baby foods and fruit juices. An estimate of the furan intake for adults revealed that $30 \%$ comes from the consumption of coffee. Children have the highest intake of furan through potato crisps and breakfast cereals. It is worth noting that the estimate of the total median furan exposure for adults (15-75 years old) reached $26 \mu \mathrm{g} /$ day and $4 \mu \mathrm{g} / \mathrm{day}$ for children (10-12 years old). Since a genotoxic mode of action could be associated to furan-induced tumor formation; current Chilean dietary exposure level to this contaminant may indicate a risk to human health and a need for its mitigation. 